Arch. histol. jap. Vol. 29, No. 5 (1968) p. $427-445$

Department of Veterinary Anatomy (Prof. S. MıкамI), Iwate University School of Agriculture, Morioka, Japan

\title{
Cytological and Cytochemical Investigations of the Adenohypophysis of the Sheep*
}

\author{
Shin-ichi Mikami and Tateo Daimon \\ （見上晋一と大門建夫） \\ Received June 17, 1968
}

Cytological and histochemical investigations of the adenohypophysis have established the presence of five or six distinctive types of glandular cells in the pars distalis of the bat (HERlant, 1956), cat (RAGAdot, 1963), dog (Goldberg and Ghaikoff, 1952, Mikami and Ono, 1956, Purves and Griesbach, 1957), goat (Shiino, 1963) and man (Ezrin and Murray, 1963, Pearse and Van Noorden, 1963). However, the main confusion concerning the adenohypophysial cytology consists in the classification and nomenclature of the cell types. The terminological problem has been more aggravated by the development of various staining methods, which allowed identification of additional cell types. Most of the special studies of the adenohypophysial cytology have been carried out with various modifications of the Mallory stain, PAS method (MaMAnus, 1946), and aldehyde-fuchsin method (Gomori, 1950). Recently, the alcian blue (Herlant and RaGadot, 1957) and aldehyde-thionin (PAGet and Egaleston, 1959) were also found to be useful in the differential staining of basophil cell types. None of these staining methods is, however, wholly satisfactory to differentiate all types of cells simultaneously. Therefore, for the identification of each cell type of the pars distalis, it is necessary to establish the correspondence of the cell types by a careful comparison between the cells stained by a specific method and the same cells in serial sections stained by other methods. It is also important to establish the interrelationships between the various morpholo. gically distinct cell types and the cytochemical characteristics or specific physiological functions of the cells. The comparative studies are also valuable for the classification of the cell types of the adenohypophysis. However, the animals used for the adenohypophysial cytology were mostly the rat, dog and man, and a few investigations were performed on ruminants. Especially many problems remain unsolved in the sheep adenohypophysis.

The present study deals with the normal cytology and cytochemistry of the sheep adenohypophysis and the cytological changes after castration, thyroidectomy and adrenalectomy.

\section{Materials and methods}

The materials used were the hypophyses of 45 adult Corriedale sheep of both

\footnotetext{
* The investigation reported herein was supported by a Scientific Research Grant (No. 91049) from the Japanese Ministry of Education.
} 
sexes which consisted of 19 normal, 20 castrated, 3 thyroidectomized, and 3 adrenalectomized sheep. The adenohypophyses were immediately removed after slaughter, cut sagittally into four slices, and fixed in one of the following fixatives for 24 hours : sublimate-formol, Zenker-formol, Bouin-Hollande solution and Susa solution.

Sagittal sections cut serially at $3-5 \mu$ were stained by the following methods :

(1) Slight modification of trichrome method by Goldberg and Chaikoff (1952).

(2) Tetrachrome method by Herlant (1960).

( 3 ) Heidenhain's azocarmine method.

(4) Aldehyde fuchsin-light green-orange G mothod (AF/LG/OG) (HALMI, 1951).

(5) Aldehyde thionin-PAS-orange G method (AT/PAS/OG) (PAgEt and Eacleston, 1960).

(6) PAS method of McManus (1946) with orange $\mathrm{G}$ as counterstain (PAS/OG).

(7) PAS-orange G-methyl blue method (PAS/OG/MB).

a) $1 \%$ aqueous methyl blue (Wilson and Ezrin, 1954).

b) $0.5 \%$ methyl blue in picric acid (RENNELs, 1957).

( 8 ) Diazo blue B-acid green-PAS stain by Landing and Hall (1956).

(9) Alcoholic alcian blue-PAS-orange G method (AB/PAS/OG) (Purves and BAsset, 1963).

(10) Performic acid-alcian blue-PAS-orange $G$ method (PFA/AB/PAS/OG) (AdAMS and Pearse, 1959).

(11) Baker's acid hematein test for phospholipid (BAKER, 1946).

A careful comparison of the field of the serial sections was performed on two or three consecutive sections which were stained by different methods.

Extraction procedures: Freshly removed hypophyses were cut sagittally into several slices, immersed in $2.5 \%$ trichloracetic acid (BARRNET et al, 1956) for 24 hours and were subsequently fixed in sublimate-formol. The extraction test was also used on the paraffin sections fixed with Zenker-formol.

\section{Observations}

\section{A. General observations on the architecture of the adenohypophysis.}

The adenohypophysis of the sheep is composed of three distinct parts, namely, the pars distalis, pars intermedia and pars tuberalis. The residual lumen separated partially the pars distalis and the pars intermedia. Colloid was a common constituent of the residual lumen. In the present study, the cone of Wulzen which was usually observed in the bovine hypophysis was not always present in the adult sheep. The pars distalis was continuous with the pars tuberalis through the ill-defined zona tuberalis, which occupied the antero-median aspect of the pars distalis. The zona tuberalis extended to the central portion of the pars distalis and formed its central basophilic core. The peripheral area of the pars distalis consisted predominantly of acidophils. Only a few basophils and chromophobes were observed in this area (Fig. 1). 


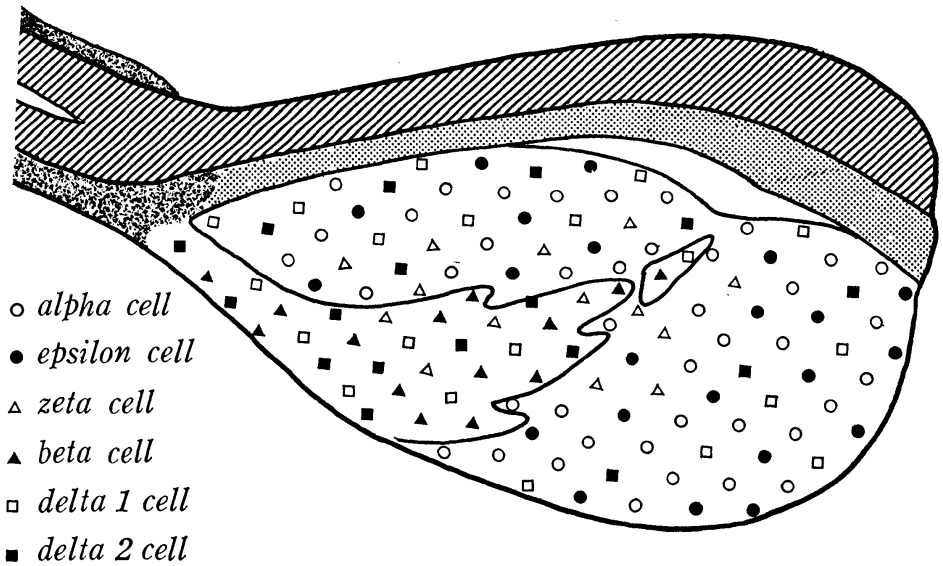

Fig. 1. Distributions of six types of glandular cells in the pars distalis of the sheep hypophysis (mid-sagittal section). The pars nervosa is marked by striae, the pars intermedia fine stipple, and the zona tuberalis is encircled by line.

\section{B. Gell types of the pars distalis.}

The glandular cells of the pars distalis were classified into six types and were designated tentatively using Greek letter nomenclature. They were two types of acidophils (alpha and epsilon), two types of amphophils (zeta and delta 1) and two types of basophils (beta and delta 2) (Table 1). The classification of the cell types was based on the tinctorial properties of their cytoplasmic granules, the shape and size of the cells, the arrangement and distribution of the cells in the gland, particularly their relationships to the sinusoids of the pars distalis.

Table 1. Staining reactions of the chromophilic cell types of the sheep adenohypophysis

\begin{tabular}{|c|c|c|c|c|c|c|}
\hline \multirow{2}{*}{ Gell types } & \multicolumn{2}{|c|}{ Acidophils } & \multicolumn{2}{|c|}{ Amphophils } & \multicolumn{2}{|c|}{ Basophils } \\
\hline & Alpha & Epsilon & Zeta & Delta 1 & Beta & Delta 2 \\
\hline $\begin{array}{l}\text { Goldberg and } \\
\text { Chaikoff's } \\
\text { trichrome }\end{array}$ & orange & red & purple & $\begin{array}{l}\text { reddish } \\
\text { purple }\end{array}$ & $\begin{array}{l}\text { dark } \\
\text { blue }\end{array}$ & $\begin{array}{l}\text { light } \\
\text { blue }\end{array}$ \\
\hline $\begin{array}{l}\text { Herlant's } \\
\text { tetrachrome }\end{array}$ & orange & red & pink & $\begin{array}{l}\text { brown } \\
\text { purple }\end{array}$ & $\begin{array}{l}\text { dark } \\
\text { blue }\end{array}$ & $\begin{array}{l}\text { light } \\
\text { blue }\end{array}$ \\
\hline $\begin{array}{l}\text { McManus' } \\
\text { PAS/OG }\end{array}$ & orange & $\begin{array}{l}\text { reddish } \\
\text { orange }\end{array}$ & red & $\begin{array}{l}\text { brick } \\
\text { red }\end{array}$ & magenta & red \\
\hline $\begin{array}{l}\text { Wilson and } \\
\text { Ezrin's } \\
\text { PAS/OG/MB }\end{array}$ & orange & $\begin{array}{l}\text { reddish } \\
\text { orange }\end{array}$ & red & $\begin{array}{l}\text { blue } \\
\text { violet }\end{array}$ & magenta & purple \\
\hline $\begin{array}{l}\text { Paget's } \\
\text { AT/PAS/OG }\end{array}$ & $\begin{array}{l}\text { light } \\
\text { orange }\end{array}$ & $\begin{array}{l}\text { reddish } \\
\text { orange }\end{array}$ & red & $\begin{array}{l}\text { blue } \\
\text { violet }\end{array}$ & magenta & violet \\
\hline $\begin{array}{l}\text { Halmi's } \\
\text { AF/LG/OG }\end{array}$ & $\begin{array}{l}\text { yellow } \\
\text { green }\end{array}$ & $\begin{array}{l}\text { yellow } \\
\text { green }\end{array}$ & $\begin{array}{l}\text { light } \\
\text { purple }\end{array}$ & $\begin{array}{l}\text { gray } \\
\text { green }\end{array}$ & $\begin{array}{l}\text { dark } \\
\text { bluish } \\
\text { purple }\end{array}$ & $\begin{array}{l}\text { gray } \\
\text { green }\end{array}$ \\
\hline $\begin{array}{l}\text { Purves' } \\
\text { AB/PAS/OG }\end{array}$ & $\begin{array}{l}\text { light } \\
\text { orange }\end{array}$ & $\begin{array}{l}\text { reddish } \\
\text { orange }\end{array}$ & red & $\begin{array}{l}\text { brick } \\
\text { red }\end{array}$ & blue & $\begin{array}{l}\text { slight } \\
\text { purple }\end{array}$ \\
\hline
\end{tabular}




\section{Acidophil types}

Two types of acidophils were identified in the pars distalis stained by the trichrome, tetrachrome, azan and PAS/OG methods. The differentiation of two types of the acidophils, alpha and epsilon, by those methods was succesful only after fixation in sublimate-formol or Bouin-Hollande solution but failed after fixation in Zenker-formol solution.

1) Alpha cell (Fig. 2,3): The alpha cells were found throughout the pars distalis proper, but only a few in the zona tuberalis. They were round or oval in shape and large in size. The nucleus was large and round and contained two or three prominent nucleoli, which were stained red with acid fuchsin. The cytoplasm contained coarse secretory granules stained with orange $\mathrm{G}$ or azocarmine. These granules were also stained with diazo blue $\mathrm{B}$ and acid hematein but did not react to PAS, aldehyde-fuchsin, aldehyde-thionin and alcian blue. Some of these cells exhibited a large negative image of Golgi zone.

2) Epsilon cell (Fig. 2, 3): The epsilon cells were distributed throughout the pars distalis proper, especially in its peripheral portion but were scarce in the zona tuberalis. They were frequently larger in size and more irregular in shape than the alpha cells. They had a round, eccentrically situated nucleus which contained a large prominent nucleolus. The cytoplasm contained fine secretory granules stained red with acid fuchsin in the trichrome method, azocarmine in the azan method and with erythrosin in the Herlant's tetrachrome method. The granules of the epsilon cells were stained reddish orange by the PAS/OG method, indicating that the granules gave a weak reaction in the PAS method and also a stainability to orange G. In some granulated cells a Golgi apparatus appeared distinctly in the juxtanuclear area which was composed of a darkly stained inner zone surrounded by a clear space.

\section{Amphophil types}

The amphophils showed a marked tendency to purple coloration, retaining the stainability to the red acid dyes and to the blue basic dyes in the trichrome or Herlant's tetrachrome methods. They were stained pink or magenta by the PAS method showing PAS-positive reaction.

Two types of the amphophils were distinguished.

1) Zeta cell (Fig. 3, 4, 5): One type of the amphophils, the zeta cells, represented large, irregular cells containing small eccentrically located nucleus and finely scattered cytoplasmic granules. They were confined to the central portion of the pars distalis. The cytoplasmic granules of these cells were stained dark purple by trichrome method, and showed red color after $\mathrm{PAS} / \mathrm{OG} / \mathrm{MB}$ or $\mathrm{AT} / \mathrm{PAS} / \mathrm{OG}$ methods, pale purple after AF/LG/OG method. They were PAS positive but AT negative and AF weakly positive. The Golgi body was not conspicuous.

2) Delta 1 cell (Fig. 2-5): The other type of the amphophils, the delta 1 cells, was small in size, round or oval in shape and contained an eccentrically placed large nucleus containing a prominent nucleolus. The cells were often rendered conspicuously with pyknotic nuclei. The delta 1 cells were distributed throughout the gland. They contained coarse secretory granules, which were stained reddish purple in the trichrome method, brick red in the PAS/OG method and purple in 

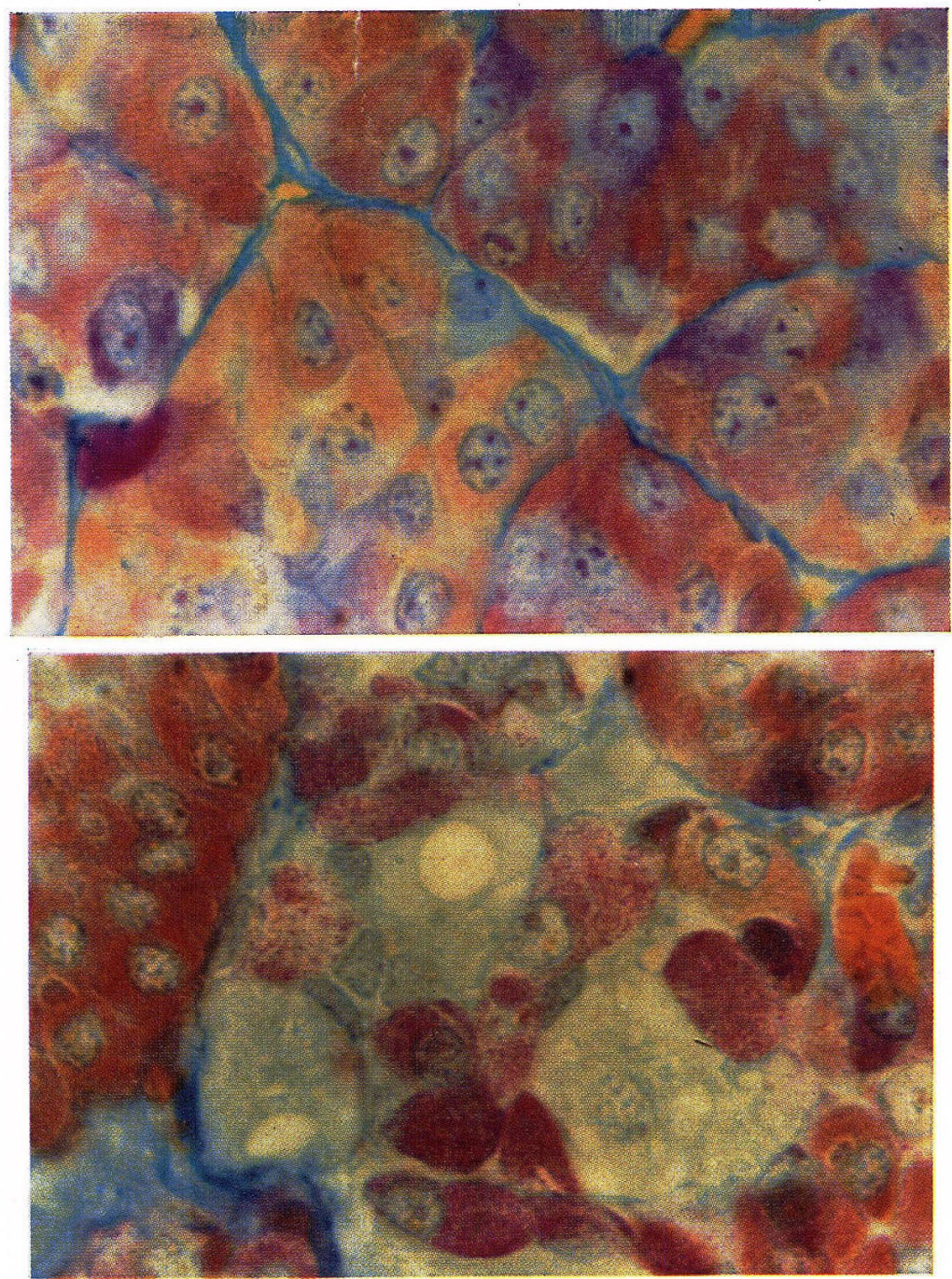

Fig. 2. The pars distalis of the adenohypophysis of the female sheep. The alpha cells are orange and the epsilon cells are reddish orange. The purple cells are the delta 1 cells and the blue cell in the center is the delta 2 cell. Fixed in Zenkerformol and stained by trichrome method. $\times 1,000$

Fig. 3. The zona tuberalis of the adenohypophysis of a thyroidectomized sheep, showing two types of acidophils, two types of amphophils and thyroidectomy cells, stained by the Herlant's tetrachrome method. The orange cells on the right are the alpha cells, and the reddish orange cells on the upper left are the epsilon cells. The large pink cells in the center are the zeta cells and the small round, purple cells on the lower part are the delta 1 cells. The thyroidectomy cells are blue, containing large or small vacuoles in their cytoplasm. Fixed in Zenker-formol. $\times 1,000$ 
the PAS/OG/MB method. They were also stained purple in the AT/PAS/OG method and grayish-green in the AF/LG/OG method, showing a weak reaction to aldehyde thionin and to aldehyde fuchsin.

\section{Basophil types}

The basophils took on a blue color when stained with aniline blue or alizarin blue in the trichrome or Herlant's tetrachrome methods and were stained pink or magenta by the PAS method showing a positive PAS reaction. Two types of basophils were distinguished.

1) Beta cell (Fig. 4, 5): One type of basophils, the beta cells, was stained dark blue with anilin blue in the trichrome method. These cells were large, polygonal in shape and were confined to the zona tuberalis, the antero-median portion of the pars distalis. The nucleus of these cells was small, irregular in form and located eccentrically. It contained two or three nucleoli. The Golgi body was poorly developed and was visible in the fully granulated cells. The granules of these cells showed magenta color in the PAS reaction and tinged dark blue-purple in AF staining. They also gave magenta color indicating a positive PAS reaction after staining by AT/PAS/OG method or PAS/OG/MB method but were not stained with aldehyde thionin or methyl blue.

2) Delta 2 cell (Fig. 2) : Basophils of another type, the delta 2 cells, were large in size, oval or round in shape and were distributed throughout the gland. These cells were stained light blue with anilin blue in the trichrome method. The nucleus was small, round and located eccentrically. The Golgi body was not conspicuous. The cytoplasmic granules of these cells were stained purple with aldehyde thionin in AT/PAS/OG method and blue purple with PAS and methyl blue in the PAS/ $\mathrm{OG} / \mathrm{MB}$ method. They were AF negative in AF/LG/OG method.

\section{Histochemical observation}

The various histochemical reactions listed in Table 2 were also used for the differentiation of each type of the cells. When Baker's acid hematein test was applied to the sections fixed in Zenker-formol or sublimate-formol, granular cytoplasmic material in the acidophils, alpha and epsilon cells, gave a positive reaction for the phospholipids. The secretory granules of the basophils and the amphophils were non-reactive to the acid hematein test while the cytoplasm of the delta 1 cells showed a weak reaction.

The McManus PAS reaction resulted in all basophils and amphophils in an intense red or magenta color indicating a high content of protein-bound carbohydrate. After the PAS/OG stain the alpha cells were stained orange only with orange G, while the epsilon cells were stained reddish orange with both PAS and orange G. This indicates that epsilon cells are weakly PAS positive. An extraction test by $2.5 \%$ trichloracetic acid showed that all secretory granules of the zeta, beta and delta 2 cells were extracted completely, but those of acidophils and delta 1 cells remained intact. This result indicates that most of extracted basophilic granules consisted of soluble glycoproteins, but those of the acidophils and the delta 1 cells contained insoluble, solid proteins.

Two types of mucoid cells could be distinguished in the sheep pars distalis using 

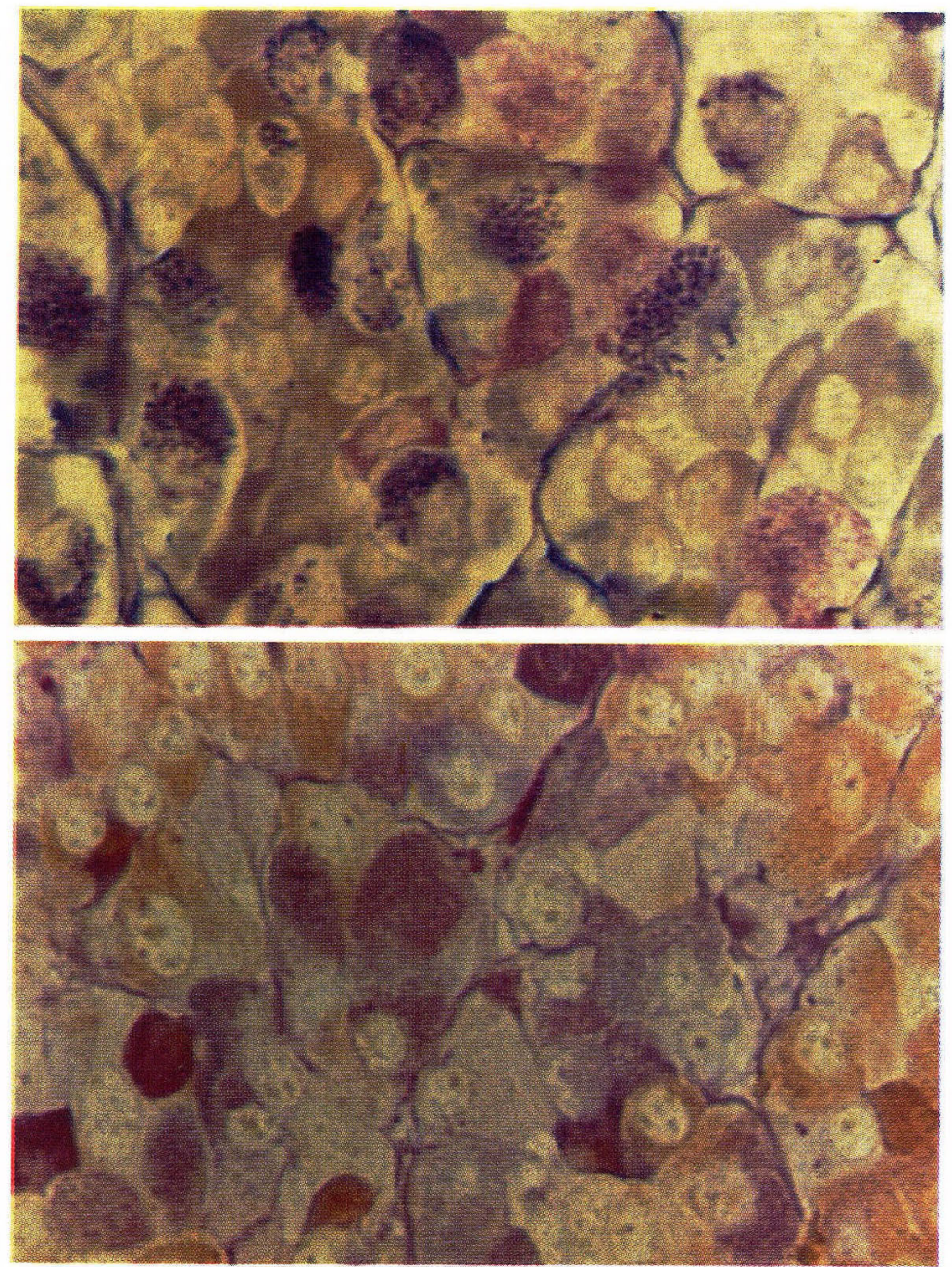

Fig. 4. The pars distalis of the adenohypophysis of the male sheep, showing purple cells stained selectively with PAS and methyl blue and red cells stained with only PAS. The round cells containing blue black granules are the delta 1 and delta 2 cells. The large polygonal cells stained red with only PAS are the beta and zeta cells. Grayish orange cells are the alpha cells and the brown cells are epsilon cells. Fixed in Bouin-Hollande solution and stained by PAS/OG/MB method. $\times 1,000$

Fig. 5. Section of the pars distalis of the sheep adenohypophysis showing two types of mucoid cells after PFA/AB/PAS/OG method. The red cells are R type resisting to performic acid and the purple cells are $S$ type. Orange cells are acidophils. Fixed in Zenker-formol. $\times 1,000$ 
Table 2. Histochemical reactions of the chromophilic cell types of the sheep adenohypophysis.

\begin{tabular}{|c|c|c|c|c|c|c|}
\hline \multirow{2}{*}{ Cell types } & \multicolumn{2}{|c|}{ Acidophils } & \multicolumn{2}{|c|}{ Amphophils } & \multicolumn{2}{|c|}{ Basophils } \\
\hline & Alpha & Epsilon & Zeta & Delta 1 & Beta & Delta 2 \\
\hline $\begin{array}{l}\text { Periodic acid-Schiff reaction } \\
\text { (PAS with amylase digestion) }\end{array}$ & - & + & ++ & +++ & +++ & ++ \\
\hline $2.5 \%$ TGA extraction & - & - & +++ & - & $+t+$ & +++ \\
\hline Steedman's alcian blue 8 GS & - & - & - & - & - & - \\
\hline Performic acid-alcian blue & - & - & - & + & ++ & + \\
\hline Acid hematein test (BAKER, 1946) & +++ & +++ & - & + & - & - \\
\hline Diazo blue B acid green & ++ & ++ & - & - & - & - \\
\hline Halmi's AF (HaLmi, 1951) & - & - & + & + & +++ & - \\
\hline Acidified permanganate acid $\mathrm{AF}$ & - & - & ++ & ++ & ++ & ++ \\
\hline Performic acid AF & - & - & ++ & ++ & ++ & ++ \\
\hline
\end{tabular}

the performic acid-alcian blue method for cystine. The PFA/AB/PAS/OG method differentiated two types of mucoid cells, $\mathrm{R}$ type and $\mathrm{S}$ type; the former was stained red and the latter purple (Fig. 5). The zeta cells were distinguished from other types of cells using this method, and stained red indicating that the cells were the $\mathrm{R}$ type, while PAS-positive cells of other types were stained purple indicating the $\mathrm{S}$ type. Therefore, the granules of the zeta cells which are of the $\mathrm{R}$ type, are resistant to performic acid and are considered to contain little cystein.

With aldehyde fuchsin prepared by Halmi's method beta cells were stained deep purple but it was ruled out by other basophils and amphophils. This method enabled a differentiation of beta cells from zeta and delta cells. After oxidation with acidified permanganate acid, aldehyde fuchsin stained the amphophils as well as the basophils deep purple.

After Landing and Hall's diazo blue B-acid green-PAS staining the basophils and amphophils were stained red to dark red, while the acidophils were bright green. This result showed that the acidophils were colored by coupling with an azo compound but the basophils and amphophils reacted in a variation of PAS.

\section{Cytological changes in the adenohypophysis following gonadectomy.}

Gonadectomized sheep used in this study were maintained under the normal conditions for nine months after the operation. The adenohypophyses of castrated sheep were larger in size than those of normal sheep. The delta 1 and delta 2 cells showed an increase in number and hypertrophy to their maximum size and were coarsely granulated being stained deeply in PAS. These hypertrophied cells which occurred throughout the gland corresponded to castration cells (Fig. 8A). Typical castration cells were large, oval or round in form and contained large or small vacuoles, which gradually developed with the growth of the cells and finally filled the whole cytoplasm (Fig. 6). Hyaline substance was rarely found in the vacuoles. The nuclei were hypertrophied and located eccentrically. Sometimes they showed a pyknotic appearance. The granules were accumulated in the cytoplasm around the nuclei and stained blue or purple in trichrome method, magenta in the PAS, purple 

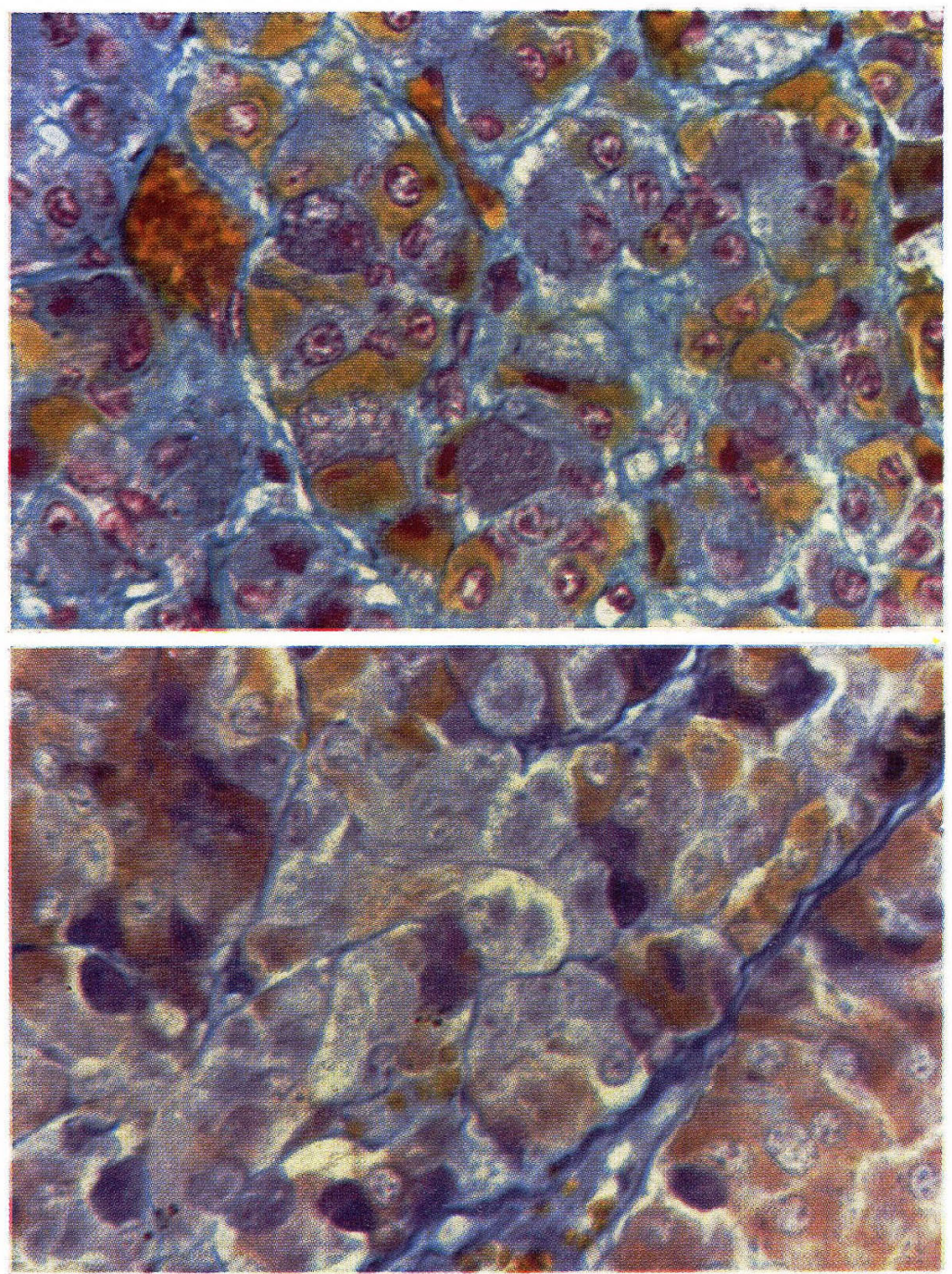

Fig. 6. Castration cells in the pars distalis of the adenohypophysis of the gonadectomized sheep. The castration cells are large, round or polygonal and contain large vacuoles in their blue- or purple-stained cytoplasm. The orange cells are the acidophils. Fixed in Bouin solution and stained by trichrome method. $\times 420$ Fig. 7. The pars distalis of the adenohypophysis of the sheep 21 days after unilateral adrenalectomy. The hypertrophied bluish purple cells are adrenalectomy cells showing marked degranulation. The orange cells are the alpha cells and the reddish orange cells are the epsilon cells. Fixed in Zenker-formol and stained by trichrome method. $\times 420$ 

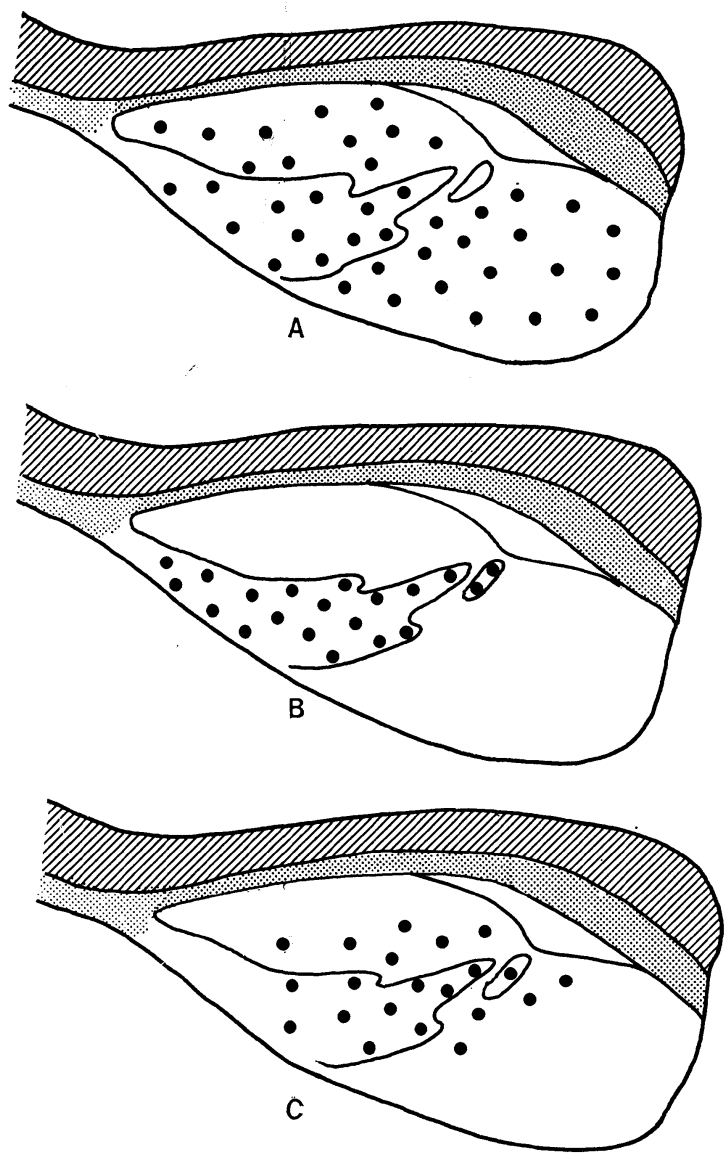

Fig. 8. Distributions of (A) castration cells, (B) thyroidectomy cells and (C) adrenalectomy cells in the pars distalis of the sheep hypophysis. in the PAS/OG/MB method. They showed grayish-green color after staining by $\mathrm{AF} / \mathrm{LG} / \mathrm{OG}$ method (Table 3 ).

The zeta and beta cells showed no remarkable change in their number, granulation, shape and staining intensity after gonadectomy. No marked alteration was observed in the number and cytological structure of the acidophils. The reaction of the acidophils to the acid hematein test was almost similar to that of normal controls.

\section{E. Cytological changes in the adenohypophysis fol- lowing thyroidectomy.}

On the 7th day after thyroidectomy, beta cells increased slightly in number and enlarged in size. Some beta cells were degranulated. On the 14th day, the beta cells were almost completely degranulated and hypertrophied remarkably. These enlarged beta cells can be identified as thyroidectomy cells since they were characterized by multiple vesicle formation in their cytoplasm. They occurred in the zona tuberalis and its extended area of the pars distalis (Fig. 8B). The thyroidectomy cells were extremely large in size and irregular or polygonal in form (Fig. 3). The nuclei of the thyroidectomy cells were also enlarged and contained prominent nucleoli stained with acid fuchsin. The Golgi body was hypertrophied showing a circular form close to the nucleus. The thyroidectomy cells of vesicular type contained smaller or larger hyaline vesicles in their cytoplasm which were stained homogeneously light blue contrasting to the granular cytoplasm. The hyaline vesicles showed a weak reaction in PAS and frequently contained AF positive coarse granules. The cytoplasmic granules of the thyroidectomy cells were sparse and stained dark blue in trichrome, red in PAS and purple in AF/LG/OG, PAS/OG/MB and AT/PAS/OG methods (Table 3).

The zeta cells increased slightly in number but did not show any cytological change such as in the thyroidectomy cells. The delta 1 and delta 2 cells also did not show any remarkable change after thyroidectomy. The alpha cells reduced remark- 
Table 3. Comparison between the castration, thyroidectomy and adrenalectomy cells in the sheep

\begin{tabular}{|c|c|c|c|}
\hline Cell types & $\begin{array}{l}\text { Castration } \\
\text { cells }\end{array}$ & $\begin{array}{l}\text { Thyroidectomy } \\
\text { cells }\end{array}$ & $\begin{array}{l}\text { Adrenalectomy } \\
\text { cells }\end{array}$ \\
\hline $\begin{array}{l}\text { Shape and } \\
\text { size of cells }\end{array}$ & $\begin{array}{l}\text { large, round } \\
\text { or oval shape }\end{array}$ & $\begin{array}{l}\text { irregular polygonal } \\
\text { shape, larger than } \\
\text { that of castration cells }\end{array}$ & $\begin{array}{l}\text { irregular polygonal, } \\
\text { smaller than } \\
\text { the other two }\end{array}$ \\
\hline Distribution & $\begin{array}{l}\text { throughout the } \\
\text { pars distalis }\end{array}$ & $\begin{array}{l}\text { zona tuberalis and } \\
\text { its extended area }\end{array}$ & $\begin{array}{l}\text { zona tuberalis and } \\
\text { central area of } \\
\text { pars distalis }\end{array}$ \\
\hline $\begin{array}{l}\text { Shape and } \\
\text { location of } \\
\text { nuclei }\end{array}$ & $\begin{array}{l}\text { round, large } \\
\text { located } \\
\text { centrally }\end{array}$ & $\begin{array}{l}\text { round, enlarged and } \\
\text { located eccentrically }\end{array}$ & $\begin{array}{l}\text { round, located } \\
\text { centrally }\end{array}$ \\
\hline $\begin{array}{l}\text { Cytoplasmic } \\
\text { structure }\end{array}$ & $\begin{array}{l}\text { contained } \\
\text { small or large } \\
\text { vacuoles } \\
(\text { PAS - ) }\end{array}$ & $\begin{array}{l}\text { contained small } \\
\text { or large hyaline } \\
\text { vesicles } \\
(\mathrm{PAS}+)\end{array}$ & $\begin{array}{l}\text { contained clear } \\
\text { vacuoles } \\
(\text { PAS - ) }\end{array}$ \\
\hline $\begin{array}{l}\text { Granules and } \\
\text { their location }\end{array}$ & $\begin{array}{l}\text { uniformly } \\
\text { granuated } \\
\text { around the } \\
\text { nuclei }\end{array}$ & $\begin{array}{l}\text { scarcely granulated } \\
\text { and scattered in the } \\
\text { cytoplasm among } \\
\text { the vesicles }\end{array}$ & $\begin{array}{l}\text { scarcely granulated } \\
\text { among the vacuoles }\end{array}$ \\
\hline $\begin{array}{l}\text { Staining } \\
\text { properties of } \\
\text { granules }\end{array}$ & $\begin{array}{l}\mathrm{AF}- \\
\text { AT } \# \\
\text { PAS } \# \\
\text { trichrome; blue } \\
\text { or purple }\end{array}$ & $\begin{array}{l}\text { AF }+ \\
\text { AT }+ \\
\text { PAS H } \\
\text { trichrome; blue }\end{array}$ & $\begin{array}{l}\mathrm{AF}- \\
\mathrm{AT}- \\
\mathrm{PAS}+ \\
\text { trichrome ; purple }\end{array}$ \\
\hline
\end{tabular}

ably in number being accompanied by a marked degranulation, while hyaline vesicles or pyknotic nuclei were not observed. These degranulated alpha cells were easily differentiated from epsilon cells, which showed no remarkable degranulation. A progressive loss of the phospholipid content of the alpha cells was observed in the sections stained with the acid hematein test.

\section{F. Cytological changes in the adenohypophysis following adrenalectomy}

Twelve hours after bilateral adrenalectomy, the only change discernible by any of the staining methods was a slight degranulation of the zeta cells.

Twenty-four hours after bilateral adrenalectomy, all chromophils of the pars distalis showed noticeable reduction in size and number. The basophils were remarkably degranulated and contained large hyaline vacuoles in their cytoplasm. The acidophils also reduced remarkably in number being accompanied by marked degranulation.

Twenty-one days after unilateral adrenalectomy, the zeta cells, which were distributed in the central portion of the pars distalis, showed remarkable increase in their size and number and degranulated slightly (Fig. 7). These altered zeta cells were stained purple by trichrome method. Their remaining granules showed a weak positive reaction in PAS. They were easily differentiated from the castration cells or thyroidectomy cells by their cytoplasmic structure and staining properties (Table 3 ). The name adrenalectomy cells was given to these cells because of their unique appearance of cytological reactions after adrenalectomy. They appeared to have 
developed from the zeta cells. No marked change was shown in number and cytological structures of other types of cells, except the slight reduction and degenerative changes in the basophils.

\section{Discussion}

The glandular cells of the pars distalis had been classified into three types, acidophils, basophils and chromophobes, until the development of staining methods allowed identification of additional cell types, which were distinct in morphology as well as in physiologic function. Romeis (1940) defined the method in which each type of granule is demarcated from other types by staining reactions and other properties, and proposed the Greek letter nomenclature for the classification of the cell types. Recently, the presence of at least six distinctive cell types has been inferred in the pars distalis of the bat (Herlant, 1956), dog (Goldberg and Ghaikoff, 1952, Mikami and Ono, 1956, Purves and Griesbach, 1957) and man (Ezrin and Murray, 1963, Pearse and Van Noordon, 1963). Although, most of the authors have used the Greek letter nomenclature for the adenohypophysial cell types, some of them either misled the Romeis' nomenclature or used different terminology. Thus, the use of various nomenclatures is a cause of the main confusion on the adenohypophysial cytology at present. Neverthless, in this paper the authors employed the Greek letter nomenclature with detailed descriptions of the morphology of each type of cell, because of the lack of appropriate terminology at present for the cell types of the pars distalis. This will be replaced by a definite nomenclature in future, when such be accepted by all investigators.

In the pars distalis of the ovine hypophysis, six types of glandular cells were identified using various tinctorial methods and cytochemical reactions. They were two types of the acidophils, two types of the amphophils and two types of the basophils, and were designated tentatively using Greek letter nomenclature as the alpha, epsilon, zeta, delta 1 , beta and delta 2 cells.

In the pars distalis of the bovine adenohypophysis, GiLmore et al. (1941) divided acidophils into two types, but BAsset (1951) and JubB and MaEntee (1955) did not distinguish the two types of acidophils. Purves (1961) reported on the acidophils of the ovine hypophysis that the Crossmon's method gave two shades of red-orange or orange-red but were distinguished from each other only with difficulty. In the present investigation of the ovine adenohypophysis, two types of acidophils were recognized after staining by the trichrome, Heidenhain's azocarmine, and Herlant's tetrachrome methods. The granules of the alpha cells were stained distinctly with orange $\mathrm{G}$, whereas those of the epsilon cells were stained red with acid fuchsin, azocarmine or erythrosin in the methods described above. The staining properties of the alpha cells were similar to those of the ordinary acidophils or alpha cells, and those of the epsilon cells were similar to those of the carminophils or erythrosin cells, which were described in the dog (Hertmann et al., 1946, Goldberg and Chaikoff, 1952, Mikami and Ono, 1956), cat and rabbit (DAwson and Friedgood, 1937), goat (YAMAOKA, 1954) and human (Romeis, 1940).

After the PAS/OG method, the alpha cells were stained orange, while the epsilon cells were stained reddish orange with both PAS and orange G. This indicates that the granules of the epsilon cell gave a weakly positive PAS reaction. Purves 
and Griesbach (1957) used preliminary buffer extraction before fixation and found that the carminophilic granules in the dog were insoluble and were still stainable by PAS after extraction at $\mathrm{pH} 7.5$, a treatment that dissolves all the basophil granules. They, therefore, defined that the granules of carminophils might be insoluble protein but not glycoprotein. In the presenl study, $2.5 \%$ trichloracetic acid did not extract the granules of both alpha and epsilon cells. After Landing and Hall's diazo blue B-acid green-PAS stain only the acidophils were colored light green by coupling with an azo compound. After Baker's acid hematein test, a positive reaction was obtained in the granules of the acidophils, but not of the basophils and amphophils. These histochemical results may indicate that the nature of the granules of the epsilon cells is not glycoprotein but insoluble protein, which is different from those of the basophils.

In the pars distalis of the thyroidectomized sheep, the alpha cells reduced remarkably in number being accompanied by a marked degranulation, but no change was observed in the epsilon cells. The alpha cells correspond to the ordinary acidophils and may be considered to be STH cells, while the epsilon cells are similar in their staining properties to the pregnancy cells described by DAwson and FrIEDGOOD (1937) and may be considered to be LTH cells.

In the cytology of the pars distalis, more confusions prevail in the classification of the basophilic type of cells. In the present investigations on the sheep adenohypophysis, the cells of basophilic type, which were PAS positive, were divided tentatively into two categories : the basophils and the amphophils. The basophils were stained blue with aniline blue and were subdivided into two types: beta and delta 2 cells. The amphophils were stained purple with both aniline blue and redacid dyes by the trichrome or tetrachrome methods and consisted of the zeta cells and delta 1 cells.

Halmi $(1950,1951)$ demonstrated two types of basophils, beta and delta cells, in the rat hypophysis using a modification of Gomori's AF method. The granules of the beta cells were stained violet and those of the delta cells green to blue green. These cells were designated by Purves and Griesbach (1951) as thyrotrophs and gonadotrophs respectively. In the bovine hypophysis, JubB and MaEnTEe (1955) divided the basophils into beta and delta types, employing the PAS reaction and Gomori's AF method. They considered that the beta cells are thyrotrophs and delta cells gonadotrophs ( $\mathrm{LH}$ cells), since the beta cells were enlarged and vacuolated in response to thyroxine deficiency whereas the delta cells showed degranulation during the first hour of oestrus when the luteinizing hormone was released. In the pars distalis of the sheep, the granules of large, angular beta cells were strongly stained by Halmi's modification of Gomori's AF method, in accordance with the descriptions of Halmi (1950, 1951), Purves and Griesbach (1951) and Jobb and MaEntee (1955).

The use of a saturated solution of alcian blue in acidified $70 \%$ alcohol was recommended by PuRves (1961) for the staining of thyrotrophs. In the sheep hypophysis, AF positive beta cells were stained blue with alcoholic alcian blue, but the specificity of the staining was lower than in aldehyde fuchsin.

Adams and Swettenham (1958) described that the granules of the mucoid cells could be divided into two types, $S$ and $R$ granules, by the PFA/AB/PAS/OG method. Pearse (1959) considered that the $\mathrm{S}$ type granules contained cystine in a 
relatively high concentration. According to Adams and Pearse (1959) the cells containing $\mathrm{S}$ type granules are gonadotrophs and those containing $\mathrm{R}$ type granules are thyrotrophs. However, Punves $(1963,1966)$ reported that the beta group of Romeis (1940) was divided into two types, theta and zeta cells, and that the zeta cells were $\mathrm{R}$ type but theta and delta cells were $\mathrm{S}$ type after PFA/AB/PAS/OG method in the human adenohypophysis. In the sheep adenohypophysis stained by $\mathrm{PFA} / \mathrm{AB} / \mathrm{PAS} / \mathrm{OG}$ method, the zeta cells were stained red indicating they were $\mathrm{R}$ type, but the beta, delta 1 and delta 2 cells were stained blue showing $\mathrm{S}$ type.

Using PAS/OG/MB method in the rat adenohypophysis, WILson and Ezrin (1954) distinguished two types of basophils under the names of "PAS-red" and "PASpurple", and correlated the former to the thyrotrophs and the latter to the gonadotrophs, respectively. In the sheep adenohypophysis, these two types of PAS positive cells, were also differentiated by the PAS/OG/MB method. It was identified that the PAS red cells were zeta and beta cells and that the PAS-purple cells were delta 1 and delta 2 cells.

Paget and Egcleston (1960), using aldehyde-thionin method combined with PAS and fast blue, differentiated blue-black thyrotrophs, red gonadotrophs and green acidophils in the adenohypophysis of the rat and dog. EZRIN and MURRAY (1963) identified seven separate cell types in the human pars distalis by the AT/PAS/ OG method and described that AT stained beta 2 and delta 1 cells selectively. They also described that the beta 1 cells in the human hypophysis were of a large, angular form and heavily granulated with PAS positive but AT negative materials. Three types of basophilic cells were recognized in the sheep pars distalis stained with the AT/PAS/OG method. One type was colored blue-black with granules heavily stained by AT. Second type was purple, less stained by AT, and third type was red without granules stained by AT. Consecutive sections stained with the AF, PAS/ $\mathrm{OG} / \mathrm{MB}$ or trichrome methods identified the blue-black cells as delta 1 cells, purple cells as delta 2 cells and red cells as beta and zeta cells. Therefore, it is obvious that AT stained the delta 1 and delta 2 cells selectively but did not stain the zeta and beta cells in the pars distalis of the sheep, in contrast with the descriptions of PAGET and Egcleston (1960) and of Ezrin and Murray (1963).

The zeta cells in the sheep hypophysis were the large irregular cells which were distributed in the central portion of the pars distalis. Their cytoplasmic granules were PAS positive but AF and AT negative, and showed a red color after the PAS/ OG/MB method and the PFA/AB/PAS/OG methods. Therefore the zeta cells are similar to the zeta cells of the hypophysis of the human (Purves, 1966), dog (Goldberg and Chaikoff, 1952, Mikami, 1956) and goat (Shirno 1963) in respect to their staining properties, and correspondence to the "PAS red cells" (Wilson and Ezrin, 1954), beta 1 cells (Ezrin and Murray, 1963) and R-type cells (Pearse and Van NoORdon, 1963) of the human hypophysis and to purple beta cells of the rat (Purves, 1963).

In the adrenalectomized dog, Miкамi (1956) found that the zeta cells increased in size and number, degranulated and developed into adrenalectomy cells. They were identified as corticotrophs. Ezrin and MURRAy (1963) also considered the beta 1 cells in the human hypophysis as the source of ACTH. RAGADOT (1963) has identified the corticotrophs in the cat hypophysis as large chromophobic cells containing 
rich ribonucleic acid. These cells became strongly active in the cat given amphenone, which resulted in a remarkable adrenal enlargement. Using the autoradiography, Fleanor and Siperstein (1963) reported that the adrenalectomy cells were the site of ACTH production and might be derived from chromophobes. After adrenalectomy in the sheep, the zeta cells increased in number and size and showed remarkable hypertrophy accompanied by degranulation-the characteristic changes of the adrenalectomy cells. No marked alteration was observed in the cytological structure of other type of cells. This implies that the zeta cells are the only element concerned with the production of ACTH.

The beta cells, one type of basophils, were large, polygonal cells stained dark blue in the trichrome method, and confined to the zona tuberalis. The granules of the beta cells were PAS positive and were stained specifically by AF and AB but not stained by AT. The beta cells are similar in staining properties to the beta cells of the rat (Halmi, 1950, 1951), dog (Goldberg and Chikoff, 1952, Mikami and Ono, $1956,1957)$ and human (Romeis, 1940), and may correspond to the beta 2 cells (Ezrin, 1963), theta cells (Purves, 1966) and S 2 cells (Pearse and Van Noordon, 1963) of the human hypophysis and "PAS red cells" of the rat adenohypophysis (Wilson and Ezrin, 1954).

After thyroidectomy, the beta cells were enlarged, degranulated and developed into typical thyroidectomy cells, which contained a number of larger or smaller vesicles in the cytoplasm. There is no disagreement among the investigators on the interpretation that the thyroidectomy cells are an activated form of TSH cells. Therefore, the beta cells are identified as thyrotrophs.

The delta 1 cells were small, round or oval cells which contained coarse secretory granules stained dark purple by the trichrome method. The granules were PAS and AT positive but AF negative. They showed purple color after the PAS/OG/MB method and $\mathrm{S}$ type after the PFA/AB/PAS/OG method. The delta 2 cells were large, oval or round cells which contained fine secretory granules stained light blue by the trichrome method. The granules showed a weak positive reaction in PAS and AT but not in AF. The delta 1 cells and delta 2 cells are similar to the delta cells of the rat (Halmi, 1951, 1952), dog (Goldberg and Chaikoff, 1952, Mikami and Ono, 1956) and cow (Jовв and MaEntee, 1955) and may correspond to the "PAS purple cells" (WILson and Ezrin, 1954) and delta cells of the human (RomEIs, 1940).

After gonadectomy, the delta 1 and delta 2 cells increased in number, hypertrophied to their maximum size and developed into typical castration cells. Castration cells were found to occur throughout the pars distalis. No marked change was observed in the cytological structure of the zeta and beta cells. Therefore, the delta 1 cells and delta 2 cells are considered to be gonadotrophs in the sheep adenohypophysis. BARRnetT et al. (1956) reported that 2.5\% TCA extracted FSH and TSH completely but did not remove LH as revealed by bioassay in the rat adenohypophysis. In the present study on the sheep adenohypophysis, all granules of the beta, zeta and delta 2 cells were extracted by $2.5 \%$ TCA, while the granules of the delta 1 cells were not. Therefore, it is expected that the delta 1 cells correspond to LH cells and the delta 2 cells to FSH cells, though further physiological investigations are necessary to confirm these relations. 
Several problems remain unsolved in this investigation. The identification of the cell types described by different authors was often difficult to follow, because the differences in descriptions were reflected by differences in experimental animals, in methods and in interpretation. There were also some disagreements as to the staining properties of certain types of cells. For instance, it is generally considered that the beta cells (thyrotrophs) are selectively stained by the AT method, while the beta cells of the sheep adenohypophysis are ruled out. However, further comparative investigations would be required to draw the conclusion that the apparent differences in staining affinities of basophilic type of cells in AT stain are due to a real cytological difference among the species.

\section{Summary}

Six types of cells were identified in the pars distalis of the sheep adenohypophysis using various tinctorial methods and cytochemical reactions: They were two types of acidophils (alpha and epsilon), two types of amphophils (zeta and delta 1) and two types of basophils (beta and delta 2). Various experiments such as castration, thyroidectomy and adrenalectomy were carried out to examine the changes in each cell type.

The alpha cells were stained orange with orange $\mathrm{G}$ in trichrome or tetrachrome methods and showed acid hematein positive but PAS negative reaction. They were located throughout the gland except the zona tuberalis.

The epsilon cells were stained red with acid fuchsin, azocarmine or erythrosin and showed positive reaction for the acid hematein test and PAS method. They were larger than the alpha cells and were distributed throughout the pars distalis especially in its peripheral area.

The zeta cells were amphophilic cells stained purple with aniline blue and acid fuchsin in trichrome method. Their granules were PAS positive, but AF and AT negative, and were $\mathrm{R}$ type after the PFA/AB/PAS/OG method. The zeta cells were large, irregular or polygonal cells distributed in the central portion of the pars distalis. They were considered to be the only source of ACTH, since they increased in number and size and showed a marked degranulation after adrenalectomy.

The beta cells were large polygonal basophils which were confined to the zona tuberalis. The PAS positive granules of the beta cells were stained selectively by AF and alcian blue but not by AT or methyl blue. The beta cells were considered to be thyrotrophs, because, after thyroidectomy, they became enlarged and degranulated cells identical with thyroidectomy cells.

The delta 1 cells were small, round or oval amphophilic cells stained reddish purple with both aniline blue and acid fuchsin in the trichrome method. They were distributed throughout the pars distalis. Their granules were coarse and stained blue-black or purple in AT, purple in PAS and methyl blue, but not stained by AF.

The delta 2 cells were large, oval or rounded basophilic cells and were stained light blue with aniline blue in the trichrome method. The granules of delta 2 cells showed a weak positive reaction for PAS and AT but not for AF. After castration, the delta 1 and delta 2 cells increased in number and size, degranulated, and developed into castration cells, which contained larger or smaller vacuoles in their cytoplasm. These cells were considered to be gonadotrophs. 


\section{ヒツジの下垂体前葉の細胞学的ならびに細胞化学的研究（内容自抄）}

各種の染色法および細胞化学的方法によってヒツジの下垂体前葉の細胞型を検討し， 2 型の酸好性細胞 ( $\alpha$ 細胞之 $\varepsilon$ 細胞)， 2 型の両好性細胞 ( $\zeta$ 細胞之 $\delta_{1}$ 細胞)， おょよび 2 型の 塩基好性細胞（ $\beta$ 細胞と $\delta_{2}$ 細胞）の 6 型を区別した。ささらに去勢，甲状腺除去，副腎除去 による各細胞の変化を検討した。

1. $\boldsymbol{\alpha}$ 細胞之 $\varepsilon$ 細胞はともに酸好性細胞で燐脂質を含み，アゾ色素と結合する， $\boldsymbol{\alpha}$ 細胞 はトリクロームまたはテトラクローム染色でオレンジ G に好染するが， $\varepsilon$ 細胞は酸フクシ ン，エリスロシン，アゾカルミンなどで好染し，PASに弱い反応を示すが，水溶性の糖蛋白 は含まない。

2. 両好性細胞 ( $\zeta$ 細胞と $\delta_{1}$ 細胞) は酸性色素と塩基性色素に同時に染まり，PAS に陽 性である。と細胞の顆粒はアルデヒドフクシン (AF) に弱く反応するが，アルデヒドチオ ニン (AT) やメチル青 (MB) に染まらず, 過蟻酸一アルシアン青一PAS (PFA/AB/PAS) 法で $\mathrm{R}$ 型を示す. $\zeta$ 細胞は副腎除去によって著明な脱顆粒を起として肥大し，副腎除去細 胞になるので, AGTH 産生細胞と考えられる。

3. 塩基好性細胞はアニリン青に好染し，PAS に陽性である. $\beta$ 細胞と $\boldsymbol{\delta}$ ，細胞の 2 型が ある. $\beta$ 細胞は zona tuberalis のみに分布し，その顆粒は PAS や AF に強い陽性を示すが， $\mathrm{AT} や \mathrm{MB}$ に染まらない. $\mathrm{PFA} / \mathrm{AB} / \mathrm{PAS}$ 法で $\mathrm{S}$ 型を示す. 甲状腺除去後, 著明に肥大し て空胞化し，甲状腺除去細胞になるので，TSH 産生細胞である.

4. $\boldsymbol{\delta}_{1}$ 細胞は両好性細胞， $\boldsymbol{\delta}_{2}$ 細胞は塩基好性細胞であるが，ともに AF には染まらない が， $\mathrm{PAS}, \mathrm{MB}, \mathrm{AT}$ に濃染し， $\mathrm{PFA} / \mathrm{AB} / \mathrm{PAS}$ 法で $\mathrm{S}$ 型を示す。ともに去勢後, 増数肥

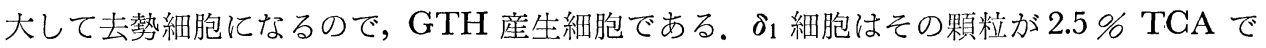
抽出されないので LH 産生細胞であろう.

\section{References}

Adams, G. W. H. and A. G. E. Pearse : Classification of the mucoid (basophil) cells in the normal and pathological human adenohypophysis. J. Endocrinol. 18:147-153 (1959).

Adams, C. W. H. and K. V. Swettenham : The histochemical identification of two types of basophil cell in the normal human adenohypophysis. J. Pathol. Bacteriol. 75:95-103 (1958).

Baker, J. R.: The histochemical recognition of lipide. Quart. J. microsc. Sci. 87 : 441-470 (1946).

Barrnett, R. J, A. J. Ladman, N. J. McAllaster and E. R. Siperstein: The localization of glycoprotein hormones in the anterior pituitary glands of rats investigated by differential protein solubilities, histological stains and bioassays. Endocrinology $59: 398-418$ (1956).

Barrnett, R. J., W. D. Roth and J. Salzer : The histochemical demonstration of the sites of luteotropic hormone in the rat pituitary gland. Endocrinology 69: 1047-1059 (1961).

Bassett, E. G.: The anterior lobe of the cattle pituitary. I. Quantitative cell type variations in various normal and abnormal sexual conditions. J. Endocrinol. $7: 203-214$ (1951).

Dawson, A. B. and H. B. Friedgood : Differentiation of two classes of acidophiles in the anterior pituitary of the female rabbit and cat. Stain Technol. $13: 17-21$ (1938).

Ezrin, C. and S. Murray: The cells of the human adenohypophysis in pregnancy, thyroid disease and adrenal cortical disorders. In: (ed. by) J. Benoit and C. Da Lage: Gytologie de 
l'adenohypophyse. Paris, C. N. R. S., 1963. (p. 183-200).

Eleanor, R. and Ph. D. Siperstein : Identification of the adrenocorticotrophin-producing cells in the rat hypophysis by autoradiography. J. Cell Biol. 17 :521-546 (1963).

Gilmore, L. O., W. E. Peterson and A. T. Rasmussen : Some morphological and functional relationships of the bovine hypophysis. Minn. Agr. Exp. Stat. Tech. Bull. 145 (1941).

Goldberg, R. G. and I. L. Ghaikoff : On the occurrence of six cell types in the dog anterior pituitary. Anat. Rec. 112 : 265-274 (1952).

Gomori, G.: Aldehyde-fuchsin : a new stain for elastic tissue. Amer. J. clin. Pathol. 20:665-666 (1950).

Halmi, N. S.: Two types of basophils in anterior pituitary of rat and their respective cytophysiological significance. Endocrinology $47: 289-299$ (1950).

: Differentiation of two types of basophils in the adenohypophysis of the rat and the mouse. Stain Technol. $27: 61-64$ (1951).

: Two types of basophils in the rat pituitary: "thyrotrophs" and "gonadotrophs" vs. beta and delta cells. Endocrinology $50: 140-142$ (1952).

Hartmann, J. F., W. R. Fain and J. M. Wolfe : A cytological study of the anterior hypophysis of the dog with paticular reference to the presence of a fourth cell type. Anat. Rec. 95:11-27 (1946).

Harlant, M.: Corrélations hypophysogenitales chez la femelle de la Chauve-Souris, Myotis myotis (Borkhausen). Arch. Biol. $67: 89-180$ (1956).

: Étude critique de deux techniques nouvelles destinées a mettre en evidence les différentes catégories cellulaires presentes dans la glande pituitaire. Bull. Microsc. appl. $10: 37-44$ (1960).

Herlant, M. et S. Racadot : Le lobe antérieur de 1'hypophyse de la chatte au cours de la gestation et de la lactation. Arch. Biol. $58: 217-248$ (1957).

Jubb, K. V. and K. McEntee : Observations on the bovine pituitary gland. I. Review of literature in the general problem of adenohypophysial functional cytology. II. Architecture and cytology with special reference to basophil cell function. Cornell Vet. $45: 576-641$ (1955).

Landing, B. H. and H. E. Hall : Histochemical differentiation of anterior pituitary cell types by contrasting azo-coupling and mucoprotein stains. Stain Technol. 31 : 193-196 (1956).

McManus, J. F. A.: Histological demonstration of mucin after periodic acid. Nature (Lond.) 158 : 202 (1946).

Mikami, S.: Cytological changes in the anterior pituitary of the dog after adrenalectomy. (Japanese with Engl. abstr.) J. Fac. Agr. Iwate Univ. 3:62-68 (1956).

- The cytological significance of regional patterns of the adenohypophysis of the fowl. J. Fac. Agr. Iwate Univ. $3: 473-545$ (1958).

Mikami, S. and K. Ono : Cytological studies on the dog anterior pituitary with special reference to its staining properties. (Japanese with Engl. abstr.) J. Fac. Agr. Iwate Univ. 2 : 440-447 (1956).

: Cytological observation on the zona tuberalis of the anterior pituitary of the dog. (Japanese with Engl. abstr.) J. Fac. Agr. Iwate Univ. 3: 194-201 (1957).

Paget, G. E. and E. Eccleston : Aldehyde-thionin : a stain having similar properties to aldehyde fuchsin. Stain Technol. 35 : 119-122 (1959).

: Simultaneous specific demonstration of thyrotroph, gonadotroph and acidophil cells in the anterior hypophysis. Stain Technol. 35 : 119-122 (1960).

Pearse, A. G. E. : Histochemistry. London, Churchill, 1959.

Pearse, A. G. E. and S. Van Noorden : The functional cytology of the human adenohypophysis. Canad. Med. Ass. J. $88: 462-471$ (1963).

Purves, H. D. : Morphology of the hypophysis related to its function. In : (ed. by) W. C. Young : Sex and internal secretion. Baltimore, Williams and Wilkins, 1961, (Vol. 1. p. 161-239).

: Cytology of the adenohypophysis. In : (ed. by) G. W. Harris and B. T. Donovan: The pituitary gland. London, Butterwoths, 1966 (Vol. 1, p. 148-222).

Purves, H. D. and E. G. Bassett : The staining reactions of the pars intermedia cells and their 
differentiation from pars anterior cells. In : (ed. by) J. Benoit and C. Da Lage : Cytologie de 1'adenohypophyse. Paris, C. N. R. S., 1963 (p. 231-142).

Purves, H. D. and W. E. Griesbach : The site of thyrotrophin and gonadotrophin production in the rat pituitary studied by McManus-Hotchkiss staining for glycoprotein. Endocrinology 49: 244-264 (1951).

: A study on the cytology of the adenohypophysis of the dog. J. Endocrinol. 14: $361-370$ (1957).

Racadot, J.: Contribution a l'étude des types cellulaires du lobe anterieur de l'hypophyse chez quelques mammifères. In : (ed. by) J. Benoit and G. Da Lage: Cytologie de l'adenohypophyse. Paris, C. N. R. S., 1963 (p. 33-48).

Rennels, E. G.: Localization of phospholipids in the rat hypophysis. Anat. Rec. 115 : 659-671 (1953). : Two tinctorial types of gonadotrophic cells in the rat hypophysis. Z. Zellforsch. 45:464471 (1957).

Romeis, B.: Die Hypophyse. In : von Möllendorffs Handbuch der mikroskopischen Anatomie des Menschen. Vol. 6. Berlin, Springer, 1940 (p. 625).

Shiino, M. : Histological studies of the function of the cells in the anterior pituitary of milk goat. II. On the ACTH producing cells in the anterior pituitary. (Japanese with Engl. abstr.) J. Fac. Agr. Miyazaki Univ. 9:53-59 (1963).

Wilson, W. D. M. and C. Ezrin : Three types of chromophil cells of the adenohypophysis demonstrated by a modification of the periodic acid-Schiff technique. Amer. J. Pathol. 30:891-899 (1954).

Yamaoka, M. : Cytological studies on the acidophils of the anterior pituitaries of cattle, goats and pigs. (Japanese with Engl. abstr.) J. Fac. Agr. Kyushu Univ. 14 : 449-454 (1954). 